\title{
Role of Biosorption in Environmental Cleanup
}

\author{
Sameera $\mathbf{V}^{1 *}$, Naga Deepthi $\mathrm{CH}^{2 *}$, Srinu Babu $\mathbf{G}^{3}$ and Ravi Teja $\mathrm{Y}^{4}$ \\ ${ }^{1}$ Biotechnology Department, REVA Institute of Science and Technology, Bangalore University, India \\ ${ }^{2}$ Department of Microbiology, Andhra University, Visakhapatnam, India \\ ${ }^{3}$ Stanford University School of Medicine, USA \\ ${ }^{4}$ Department of Biochemistry, Dr.L.Bullayya P.G.College, Andhra University, India
}

\begin{abstract}
Pollution has been the major problem since decades, destructing our environment and resources. Among all types of pollutions, heavy metal pollution is causing major threat to the biosphere. It is mainly resulted due to the release of Industrial wastes into the atmosphere. Industries follow various chemical procedures to remove harmful pollutants from the industrial effluents associated with various disadvantages as a result many eco-friendly techniques have come into light keeping due to the disadvantages of the chemical techniques. Biosorption of heavy metals by microbial cells has been recognized as a potential alternative to existing technologies for recovery of heavy metals from industrial waste. Present review focuses on the biosorption of different metals by different means which lead to the eco friendly clean up of the environment without causing any damage as such to the surroundings/ without the release of chemicals into the atmosphere, this article mainly deals with the biosorption of $\mathrm{Fe}, \mathrm{Cr}(\mathrm{VI}), \mathrm{U}$, $\mathrm{Pb}, \mathrm{Cu} 2+, \mathrm{Cd}(\mathrm{II}), \mathrm{Mn}, \mathrm{Zn}, \mathrm{Ni}$, Lanthanides, $\mathrm{Ni}$ and the role of this technique in cleaning up of the environment.
\end{abstract}

Keywords: Heavy metals; Biosorption; Bioremediation; Biodegradation; Biodesulfurization; Hydrodesulfurization; Deionization

\section{Introduction}

Pollution is the introduction of contaminants into a natural environment that causes instability, disorder, harm or discomfort to the ecosystem. Rapid industrialization and urbanization have resulted in the release of large amount of wastes into the environment causing major pollution problem [1]. Pollution can take the form of chemical substances or energy, such as noise, heat, or light. Pollutants, the elements of pollution, can be foreign substances or energies, or naturally occurring; when naturally occurring, they are considered contaminants when they exceed natural levels [2]. Environmental pollution caused by the release of a wide range of compounds, as a consequence of Industrial progress has now assumed serious proportions. Management of water pollution is at present one of the major challenges for environmentalists [3]. Today's highly industrialized environment is charged with a multitude of potentially toxic chemicals. The presence of harmful pollutants in the discharge wastewaters often contaminates the surface water and soil. Pollution of aquatic and soil is a worldwide problem that can result in uptake and accumulation of toxic chemicals in food chains and also harm to the flora and fauna of affected habitats [4]. Soil contamination occurs when chemicals are released intentionally, by spill or underground leakage. Among the most significant soil contaminants are hydrocarbons, heavy metals, MTBE, herbicides, pesticides and chlorinated hydrocarbons [5]. Pesticides also play an important role in causing pollution. The persistent use of synthetic pesticides in agriculture, silviculture and even animal husbandry has created several difficulties on public health $[6,7]$. Problems associated with the pesticide hazards to man and environment are not confined to the developing countries, but extended to developed nations and still facing some problems in certain locations. The contamination of soils and groundwater with petroleum compounds is among the most prevalent problems worldwide [8]. Oil contamination is also one of the environmental pollutions which can be cleaned up using bio surfactants [9]. As a result of environmental pollution, release of gases like carbon dioxide, sulfur dioxide and nitrogen oxides take place which cause green house effect [10]. Accumulation of radionuclide in aquatic plants and fish can reach to the human food chain [11,12].

\section{Heavy metal pollution}

A heavy metal is a member of a loosely-defined subset of elements that exhibit metallic properties. It mainly includes the transition metals, some metalloids, lanthanides, and actinides. Many different definitions have been proposed-some based on density, some on atomic number or atomic weight, and some on chemical properties or toxicity. Heavy metals occur naturally in the ecosystem with large variations in concentration. In modern times, anthropogenic sources of heavy metals, i.e. pollution, have been introduced to the ecosystem. Waste-derived fuels are especially prone to contain heavy metals, so heavy metals are a concern in consideration of waste as fuel.

Relationship to living organisms: Living organisms require varying amounts of "heavy metals" like Iron, cobalt, copper, manganese, molybdenum, and zinc. Excessive levels of these metals can be damaging to the organism. Other heavy metals such as mercury, plutonium and lead are toxic metals that have no known vital or beneficial effect on organisms, and their accumulation over time in the bodies of animals can cause serious illness. Certain elements that are normally toxic are, for certain organisms or under certain conditions, beneficial. Examples include vanadium, tungsten and cadmium.

Heavy metal pollution and its counter effects: Heavy metal ions such as $\mathrm{Cu}, \mathrm{Cd}, \mathrm{Hg}, \mathrm{Zn}, \mathrm{Pb}, \mathrm{Cr}$ etc., are natural components of the earth's crust and cannot be degraded and have been recognized

*Corresponding author: Sameera V, Biotechnology Department, REVA Institute of Science \& Technology, Bangalore University, India, E-mail: sameera_vadapalli@ yahoo.com

Naga Deepthi $\mathrm{CH}$, Department of Microbiology, Andhra University, Visakhapatnam, India, E-mail: deepthi.chettipalli@gmail.com

Received May 01, 2011; Accepted June 10, 2011; Published June 22, 2011

Citation: Sameera V, Naga Deepthi CH, Srinu Babu G, Ravi Teja Y (2011) Role of Biosorption in Environmental Cleanup. J Microbial Biochem Technol R1:001. doi:10.4172/1948-5948.R1-001

Copyright: (c) 2011 Sameera V, et al. This is an open-access article distributed under the terms of the Creative Commons Attribution License, which permits unrestricted use, distribution, and reproduction in any medium, provided the original author and source are credited 
as ecotoxicological hazards [13]. Heavy metal pollution can arise from many sources but most commonly arises from the purification of metals, e.g., the smelting of copper and the preparation of nuclear fuels. Mine wastes have been generated from mining activities for several centuries. Mine tailings usually contain high concentrations of metals (Cu, $\mathrm{Zn}, \mathrm{Fe}, \mathrm{Mn}, \mathrm{Ni}, \mathrm{Pb}$ and $\mathrm{Cd}$ etc.) [14]. Heavy metals contamination of agricultural arable fields by frequent applications of deposited sewage sludge and industrial effluents can have long adverse effects on soil microorganisms [15]. Electroplating is the primary source of chromium and cadmium. Through precipitation of their compounds or by ion exchange into soils and mud's, heavy metal pollutants can localize and lay dormant. Unlike organic pollutants, heavy metals do not decay and thus pose a different kind of challenge for remediation. Currently, plants or microorganisms are tentatively used to remove some heavy metals such as mercury. Plants which exhibit hyper accumulation can be used to remove heavy metals from soils by concentrating them in their bio matter. Some treatment of mining tailings has occurred where the vegetation is then incinerated to recover the heavy metals. Mine wastes have been generated from mining activities for several centuries. Mine tailings usually contain high concentrations of metals $(\mathrm{Cu}, \mathrm{Zn}, \mathrm{Fe}, \mathrm{Mn}, \mathrm{Ni}, \mathrm{Pb}$ and $\mathrm{Cd}$ etc.) ranging from 1 to $50 \mathrm{~g} \cdot \mathrm{kg}^{-1}[16]$.

One of the largest problems associated with the persistence of heavy metals is the potential for bioaccumulation and biomagnification causing heavier exposure for some organisms than their presence in the environment alone. Coastal fish (such as the smooth toadfish) and seabirds (such as the Atlantic Puffin) are often monitored for the presence of such contaminants [17].

\section{Heavy metal degradation}

In response to the growing problems, federal and state governments have instituted environmental regulations to protect the quality of surface and ground water from heavy metal pollutants, such as $\mathrm{Cd}$, $\mathrm{Cu}, \mathrm{Pb}, \mathrm{Hg}, \mathrm{Cr}$, and $\mathrm{Fe}$. To meet the federal and state guidelines for heavy metal discharge, companies often use chemical precipitation or chelating agents. For acid mine drainage (AMD) and wastewater treatment plants, the typical means of removing heavy metals is usually accomplished through $\mathrm{pH}$ neutralization and precipitation with lime, peroxide addition, reverse osmosis, and ion exchange. Extensive research and financial resources have been spent on each of these treatment processes with the overwhelmingly preferred method, based upon cost and effectiveness, being precipitation through neutralization. A major disadvantage of the liming process, however, is the need for large doses of alkaline materials to increase and maintain $\mathrm{pH}$ values of 4.0 to above 6.5 for optimal metal removal. Additionally, $\mathrm{pH}$ neutralization typically requires that the materials be appreciably finegrained to provide the necessary reactive surface area. Furthermore, liming produces secondary wastes such as metal hydroxide sludge that necessitate highly regulated and costly disposal [18].

\section{Commonly used procedures}

The commonly used procedures for removing metal ions from aqueous streams include chemical precipitation, lime coagulation, ion exchange, reverse osmosis and solvent extraction. The process description of each method is presented below.

Reverse osmosis: It is a process in which heavy metals are separated by a semi-permeable membrane at a pressure greater than osmotic pressure caused by the dissolved solids in wastewater. The disadvantage of this method is that it is expensive.
Electro-dialysis: In this process, the ionic components (heavy metals) are separated through the use of semi-permeable ion selective membranes. Application of an electrical potential between the two electrodes causes a migration of cations and anions towards respective electrodes. Because of the alternate spacing of cation and anion permeable membranes, cells of concentrated and dilute salts are formed. The disadvantage is the formation of metal hydroxides, which clog the membrane.

Ultra filtration: They are pressure driven membrane operations that use porous membranes for the removal of heavy metals. The main disadvantage of this process is the generation of sludge.

Ion-exchange: In this process, metal ions from dilute solutions are exchanged with ions held by electrostatic forces on the exchange resin. The disadvantages include: high cost and partial removal of certain ions.

Chemical precipitation: Precipitation of metals is achieved by the addition of coagulants such as alum, lime, iron salts and other organic polymers. The large amount of sludge containing toxic compounds produced during the process is the main disadvantage.

Phytoremediation: Phytoremediation is the use of certain plants to clean up soil, sediment, and water contaminated with metals. The disadvantages include that it takes a long time for removal of metals and the regeneration of the plant for further biosorption is difficult.

\section{Disadvantages}

- Incomplete metal removal,

- High reagent and energy requirements,

- Generation of toxic sludge or other waste products that require careful disposal

These made it imperative for a cost-effective treatment method that is capable of removing heavy metals from aqueous effluents [19].

\section{Eco - Friendly cleanup of environment}

Public concern towards the conservation of the environment demands for new and more environmentally efficient low cost strategies for cleanup contaminated sites $[20,21]$. Since last two decades the scientific community is interested to develop efficient biological methods of waste water treatments [22]. Microbial population is a highly diverse and a ubiquitous group among the living world. One of the novel features of the microbes relates to their versatility in utilizing a large numbers of natural and manmade compounds. This property proves highly valuable in bioremediation for the complete destruction and removal of pollutants [23]. Microbial degradation is an environment friendly and cost-competitive alternative to chemical decomposition processes [24]. Many biological agents such as bacteria are efficient in degrading those pollutants even when those agents are immobilized on inert matrices [25]. In most cases, biodegradation constitutes the primary mechanism for the organic contaminant removal [26-28]. Metal resistant strains are mainly employed in the bioremediation process [29]. Many eco-friendly techniques have come into light keeping due to the disadvantages of the chemical techniques. Some examples of these are,

- Phytoremediation technology has gained attention as an ecological remediation tool for contaminated soil and water [30]. 
- Developments in Enhanced Oil Recovery (EOR) which is environmental friendly [31].

- Biodesulfurization (BDS) of fuels through microbial activities has been shown to be a potential alternative to Hydrodesulfurization [32].

- Several biorefinery processes have been developed to produce biofuels and chemicals from biomass feedstock [33].

- Employing anaerobic processes in municipal slaughter house which produce a minimal quantity of sludge with the advantage that the biogas produced can be used as a source of energy [34,35].

- Development of photo degradable or biodegradable polymers [36,37].

- Safe biodegradation of azo dyes [38].

- Biodegradation of Petroleum [39,40] and phenol [41].

- Utilization of the agro-industrial wastes, provides alternative substrates and helps in solving pollution problems, which otherwise may cause their disposal [42].

- A soil bacterium, P.putida strain CSV86 utilizes various aromatic compounds like naphthalene, methylnaphthalene, benzylalcohol, benzoate etc. as the sole carbon and energy source thereby degrading them [43].

- Use of Bio-Insecticides [44].

\section{Eco-friendly heavy metal degradation}

An extensive body of research has found that a wide variety of commonly discarded waste including eggshells, bones, peat, fungi, seaweed, yeast and carrot peels can efficiently remove toxic heavy metal ions from contaminated water. Ions from metals like mercury can react in the environment to form harmful compounds like methyl mercury, a compound known to be toxic in humans. In addition, adsorbing biomass, or biosorbent, can also remove other harmful metals like: arsenic, lead, cadmium, cobalt, chromium and uranium. Biosorption may be used as an environmentally friendly filtering technique. There is no doubt that the world could benefit from more rigorous filtering of harmful pollutants created by industrial processes and all-around human activity.

The idea of using biomass as a tool in environmental cleanup has been around since the early 1900's when Arden and Lockett discovered certain types of living bacteria cultures were capable of recovering nitrogen and phosphorus from raw sewage when it was mixed in an aeration tank. This discovery became known as the activated sludge process which is structured around the concept of bioaccumulation and is still widely used in wastewater treatment plants today. It wasn't until the late 1970's when scientists noticed the sequestering characteristic in dead biomass which resulted in a shift in research from bioaccumulation to biosorption [45].

Biosorption: Biosorption is a physiochemical process that occurs naturally in certain biomass which allows it to passively concentrate and bind contaminants onto its cellular structure. From a bioenvironmental systems point of view, "biosorption" is used generally to refer to sorption onto biomass or biofilm, i.e. an abiotic process [46]. Though using biomass in environmental cleanup has been in practice for a while, scientists and engineers are hoping this phenomenon will provide an economical alternative for removing toxic heavy metals from industrial wastewater and aid in environmental remediation [45].

The major advantages of biosorption over conventional treatment methods include [19]:

- Low cost;

- High efficiency;

- Minimisation of chemical and/or biological sludge;

- No additional nutrient requirement;

- Regeneration of biosorbent; and

- Possibility of metal recovery

The mechanism of biosorption is complex, mainly ion exchange, chelation, adsorption by physical forces, entrapment in inters and intrafibrilliar capillaries and spaces of the structural polysaccharide network as a result of the concentration gradient and diffusion through cell walls and membranes [19]. Biosorption can be an effective technique for the treatment of heavy metal bearing waste water resulting from humans and industrial activities. Several gram positive and gram negative bacteria have the ability to remove the heavy metals and thereby making water contaminant free. It has been reported that attenuated bacterial biomass have greater biosorption capability than viable cells [47]. Use of immobilized microbial cells in the field of wastewater treatment has been found to be useful because of the advantages which include long retention time of biomass in the system, ease of use in a continuous reactor and their ability for scale up [48].

The biosorption rate depends on the type of the process. According to literature, biosorption can be divided into two main processes: adsorption of the ions on cell surface and bioaccumulation within the cell [49].

Many aquatic microorganisms, such as bacteria, yeast and algae can take up dissolved metals from their surroundings onto their bodies and can be used for removing heavy metal ions successfully [50].

\section{Biosorption of heavy metals}

Most studies of biosorption for metal removal have involved the use of either laboratory-grown microorganism or biomass generated by the pharmacology and food processing industries or wastewater treatment units [50].

\section{Biosorption of Fe}

Biosorption of Fe can be carried out with the help of Syringa Vulgaris tree leaves. Ulmus Syringa Vulgaris tree leaves, which are abundant in Iran, were evaluated for removal of $\mathrm{Fe}$ from aqueous solution. Maximum biosorption capacities for Syringa Vulgaris were measured as $155.42 \mathrm{mg} / \mathrm{g}$ for Fe [51].

Method: Following steps are carried out in an experiment in which the efficiency of Fe uptake by Syringa vulgaris was calculated

$>$ The Syringa vulgaris tree leaves were gathered from twigs by clean plastic bags, washed with ion-free distilled water and then dried

$>$ The dried biomass was powdered and then stored in plastic bags to get ready for being used as a biosorbent

$>$ Metal ion solution used in this study was prepared by dilution of $1000 \mathrm{mg} \mathrm{l}^{-1}$ stock solution of Fe obtained by dissolving $\left(\mathrm{H}_{8} \mathrm{Fe}\right.$ $\mathrm{N}_{2} \mathrm{O}_{8} \mathrm{~S}_{2} \cdot 6 \mathrm{H}_{2} \mathrm{O}$ ) in distilled and deionized water. 
$>$ The biosorption of $\mathrm{Fe}$ ion on the dried yeast biomass was investigated in batch biosorption equilibrium experiments.

$>$ The effect of the initial metal ion concentration, contact time, temperature, biosorbent dose and $\mathrm{pH}$ on the biosorption rate and capacity was studied.

$>$ The effect of temperature on the biosorption capacity of the biosorbent was determined by using different temperatures;

$>$ The concentrations of heavy metal ions can be determined using an atomic absorption spectrophotometer before and after biosorption [51].

Biosorption efficiency was expressed as:

$$
\text { Removal } \quad(\%)=\left(\frac{C_{i}-C_{e}}{C_{i}}\right) \times 100
$$

$>$ The amount of adsorbed heavy metal ions per unit of biosorbent (mg metal ion / g dry biosorbent) is obtained by using the following expression [51]

$$
q_{e q}(m g / g r)=\frac{\left(C_{0}-C_{e}\right) V}{m}
$$

Effect of pH: The optimum uptake of metal ions by Syringa Vulgaris tree leaves can be observed at $\mathrm{pH} 3-9$. Increasing $\mathrm{pH}$ from to 9 results in lower biosorption with sorbent for Fe. This may be attributed to the decreased solubility of metals at high $\mathrm{pH}$ [51].

Effect of initial metal ion concentration: At low concentrations metals are adsorbed by specific sites, while with increasing metal concentrations the specific sites are saturated and the exchange sites are filled. A Biosorption capacity of sorbent is increased by increasing of metal ion concentration in the media. Sorbent exhibits very high metal loading capacities for this metal ion $155.42 \mathrm{mg} \mathrm{g}^{-1}$ for iron for Syringa Vulgaris tree leaves [51].

Effect of biosorbent-biosorbate contact time: In this process, first rapid initial uptake is followed by a slow stage reaching equilibrium. The rapid stage is probably due to the abundant available active sites on the biomass, and with the gradual occupancy of these sites, the sorption becomes less efficient in this lower stage. The fast metal uptake by the sorbent may be attributed to its highly porous and mesh structure, which provides accessibility and large surface area for the sorption of metal on the binding sites [51].

Relationship of the sorbents quantity with metal: The percentage of metal ion adsorbed increases with increasing sorbent concentration. The maximum metal ion uptake can be observed at about $10 \mathrm{~g} \mathrm{~L}^{-1}$ for Syringa Vulgaris sorbents for Fe ion [51].

\section{Biosorption of $\mathrm{Cr}$ (VI)}

Chromium is an essential micronutrient required for the growth of many organisms. However, at high concentration it is toxic, carcinogenic and teratogenic [52]. Chromium and its compounds are widely employed in industries [53] such as electroplating, chromate manufacturing, dyes and pigment manufacturing, wood preservation, leather tanning industry, manufacture of alloys and as corrosion inhibitor in conventional and nuclear power plants [52] and $\mathrm{Cr}$ (III) is used as a tanning agent, resulting in severe groundwater contamination around tanneries.
Oxidation of polyuronic acids and pectin by hipervalent Chromium showed the presence of $\mathrm{Cr}$ (V), $\mathrm{Cr}$ (IV) and Cr (III)-saccharide complexes, with $\mathrm{Cr}$ (III)-pectin as an insoluble compound in the reaction media [53]. Though chromium exists in nine valence states ranging from 2 to $+6, \mathrm{Cr}$ (III) and $\mathrm{Cr}(\mathrm{VI})$ are of major environmental significance because of their stability in the natural environment [52]. Hexavalent Chromium is known to be human carcinogen based on sufficient evidence of carcinogenicity in humans [54].

Hexavalent chromium (chromate) compounds are water soluble, toxic, and probably carcinogenic. Trivalent chromium, $\mathrm{Cr}$ (III), is less soluble and less toxic. Thus, reduction of $\mathrm{Cr}$ (VI) to $\mathrm{Cr}$ (III) represents a potentially useful detoxification process. Bacterial reduction of chromate has been widely reported but the enzymatic basis for chromate reduction has not been clarified. There is evidence for both aerobic and anaerobic reduction systems with different microbes. Anaerobic chromate reduction occurs with a membrane preparation. Aerobic chromate reductase activities (probably involving soluble proteins) have been found in other bacteria [52].

Biosorption of Cr by Pseudomonas sp: An experiment was conducted by Murugesan et al. [55] to isolate and characterize the culturable microbial community of chromium-contaminated sites and to evaluate the $\mathrm{Cr}(\mathrm{VI})$ resistance and $\mathrm{Cr}$ (VI)-reducing ability using live, dead and immobilized bacterial biomass [56].

Collection of soil samples: Soil samples can be collected from garden soil contaminated with chromium containing synthetic effluent and also receiving wastes from common burning place and effluent treatment area [56].

Isolation of chromium resistant microorganisms: The soil samples should be mixed well, serially diluted and cultured for two weeks. The colonies present on the petriplates were selected and streaked on nutrient agar plates in pure form [56].

Biosorption of Cr (VI) Using Immobilized Biomass of Bacteria: Immobilization of Pseudomonas $s p$ is carried out by the use of sodium alginate gel. The gel beads should be kept in $4 \% \mathrm{CaCl}_{2}$ solution at $5^{\circ} \mathrm{C}$ for about an hour for complete gelatin. The beads are washed with sterile distilled water and later can be used for metal biosorption study. Hexavalent chromium can be estimated spectrophotometrically using diphenyl carbazide reagent [56]. The bacterial isolates Pseudomonas Sp utilize the $\mathrm{Cr}$ (VI) up to $100 \mathrm{ppm}$ without affecting its other metabolic activities.

In the case of alginate entrapped biosorbent higher metal uptake occurs due to the better porosity of the beads which would allow metal ions to be freely transported through the matrix [56].

\section{Biosorption of uranium}

Uptake of Uranium can be brought about by using algae, bacteria, lichens, fungi, etc. Lots of studies were carried out on the biosorption of $U$ by different living organisms. One of such interesting studies was utilization of Saccharomyces cerevisiae in uptake of $\mathrm{U}$.

Among the radioactive contaminants, uranium, neptunium and plutonium are most problematic because they pose long-term environmental risks. Uranium is one of the most seriously threatening heavy metal because of its high toxic, chemical and radiological characteristics. Excessive amounts of uranium have found their ways into the environment through the activities associated with the processing of uranium ore into nuclear fuels and materials [57]. They 
accumulate in living tissues throughout the food chain which has humans at its top. These toxic metals can cause accumulative poisoning, cancer and brain damage when found above the tolerance levels [58].

Large amount of uranium can react with tissues and can cause kidney disease. It is not known to cause cancer but the daughter progeny formed after its decay, have potential to cause cancer. Threat of heavy metal or radionuclide pollution is slowly becoming a reality all over the world. Thus necessitating the monitoring of exposure level and remedial measures before it is too late [57].

Development of biosorbent: Pure culture of $S$. cerevisiae is routinely maintained by streaking on Rose Bengal Agar medium and incubating at $25^{\circ} \mathrm{C}$. For mass culturing, S. cerevisiae can be cultivated in liquid medium using the shake flask method. S. cerevisiae cells should be separated from liquid medium by centrifuge washed twice with distilled water and then dried at $100^{\circ} \mathrm{C}$ for 24 hours. Non-viable biomass can be obtained from cultured cells by heating at $80^{\circ} \mathrm{C}$ in an oven till their weight become constant. The dried samples were ground and sieved through the variant pore sizes as per requirement. The biomass thus obtained is untreated biomass. In order to generate active site and enhanced biosorption, the biomass should be treated with $0.1 \mathrm{~N} \mathrm{NaOH}$ for $6 \mathrm{hrs}$ at $30^{\circ} \mathrm{C}$. The treated biomass can be collected by centrifugation [57].

Batch biosorption procedure: All uptake experiments can be performed by suspending the biosorbent in $100 \mathrm{ml}$ of metal solution at desirable $\mathrm{pH}$, Biosorbent dose, Initial metal concentration, Contact time and Particle size. Sorption contact experiments with metalbearing solutions should be run in duplicate with a blank undergoing the same treatment [57].

The effectiveness of the removal process depends mainly on $\mathrm{pH}$ followed by amount of biomass and initial U (VI) concentration, Contact time and particle size. Base treatment of biomass significantly improves the biosorption efficiency as compared to untreated biomass. FTIR spectral analysis and chemical treatment of the biosorbent demonstrates that $S$. cerevisiae contains reasonable amount of protein and amino acids like hystidine, which serve as a matrix of $-\mathrm{COOH}$ and $-\mathrm{NH}_{2}$ groups, which in turn take part in binding of metal ion [57].

\section{Biosorption of lead}

Lead (II) poisoning in human causes severe damage to kidney, nervous system, reproductive system, liver and brain. Severe exposure to lead has been associated with sterility, abortion, still births and neo-natal deaths [59]. Process industries, such as battery manufacturing, printing and pigment, metal plating and finishing, ammunition, soldering material, ceramic and glass industries, iron and steel manufacturing units generate large quantities of waste water contaminated with lead (II). In drinking water lead (II) contamination occurs due to the corrosion and leaching of lead pipes and $\mathrm{Pb} / \mathrm{Sn}$ solder joints associated with copper service lines used in house hold plumbing [60].

Rice husk is mostly used as a fuel in the boiler furnaces of various industries to produce stream. The ash generated after burning the rice husk in the boiler is called rice husk ash. The R.H was collected from the particulate collection equipment attached up stream to the stack of rice-fired boilers. The ash generated got a server disposal problem [60]. This Rice husk ash is used in the biosorption of $\mathrm{Pb}$.

Rice husk ash as adsorbents: The rice husk (R.H.) can be received from a local rice mill, the R.H. were crushed and sieved with 0.180 ,
0.355 and 0.855 mesh sieve. Then, the husks should be thoroughly washed with a stream of distilled water to remove all dirt and then dried at $100^{\circ} \mathrm{C}$ to be constant weight. The dried husks can be stored in desiccators until used. The R.H.A can be obtained from burning of R.H husk in electrical oven at $600^{\circ} \mathrm{C}$ for $3 \mathrm{~h} \mathrm{[60].}$

The adsorption of $\mathrm{Pb}$ (II) in aqueous solution on R.H and R.H.A. were examined by optimizing various physicochemical parameters such as $\mathrm{pH}$, contact time, amount of adsorbent, adsorbent size and adsorbate initial concentration [60].

Effect of pH: Removal of $\mathrm{Pb}$ (II) increase with increasing solution $\mathrm{pH}$ and a maximum value reaches at an equilibrium $\mathrm{pH}$ of around 4.6 \pm 0.5 for rice R.H. and R.H.A. The same trend has also been reported in the removal of $\mathrm{Pb}$ (II) ions by other vegetable materials.

The low degree of adsorption at low $\mathrm{pH}$ values can be explained by the fact that at low $\mathrm{pH}$ values the $\left[\mathrm{H}^{+}\right]$ion concentration is high and therefore protons can compete with the lead cations for surface sites, since at low $\mathrm{pH} \mathrm{Pb}(\mathrm{II})$ are present in solution as $\mathrm{Pb}^{+2}$ free cations. In addition when $\mathrm{pH}$ increases, there is a decrease in positive surface charge (since the deprotonation of the sorbent functional groups could occur, which results in a lower electro static repulsion between the positively charged metal ion and the surface of R.H.A, favouring adsorption than its R.H [60].

Effect of adsorbent concentration: The removal of metal ion increases with an increase in adsorbent dosage, and this can be attributed to the availability of larger surface area and more adsorption sites. At very low adsorbent concentration, the adsorbent surface becomes saturated with the metal ions and the residual metal ion concentration in the solution to large [60].

Effect of contact time: The adsorption of $\mathrm{Pb}$ (II) increases with increasing contact time and becomes constant after a particular time. Higher adsorption efficiency of R.H.A. could be attributed to available absorbing sites (Surface functional groups) on the adsorbent surface [60].

Effect of initial metal ion concentration: The sorption capacities of the sorbents increase with increasing $\mathrm{Pb}$ (II) concentration while the adsorption yield of $\mathrm{Pb}$ (II) shows the opposite trend.

\section{Biosorption of copper}

Road runoff is considered a major anthropogenic source of heavy metals in the environment [61]. Rainfall can wash these pollutants from impervious surfaces directly into streams and lakes or they can infiltrate into the soil alongside roads [62]. Some of the heavy metals, e.g., copper $(\mathrm{Cu})$, zinc $(\mathrm{Zn})$, and nickel $(\mathrm{Ni})$ are essential elements that are required to a varying degree in plants and animals, but when present in elevated bio available concentrations, these elements can become toxic [62].

At present, there is a growing interest in the application of fungi for bioremediation of industrial effluent. The fungi have a strong potential for use in non - sterile open environment. The mycelial growth gives a competitive advantage over single cell such as bacteria and yeast, especially with respect to the colonization of insoluble substrates. They have high surface to cell ratio characteristics of filaments that maximize both mechanical and enzymatic contact with the substrate. Metal uptake capacity of various fungal biosorbent has been evaluated using biosorption isotherm curves derived from equilibrium batch sorption 
experiment. Effect of various process parameters such as $\mathrm{pH}$, biomass loading, biomass pre-treatment, etc, has been studied extensively [63].

One example for the fungi which can be used for the $\mathrm{Cu}$ removal is A lentulus fungal strain. The biosorbent can be prepared by subjecting a lentulus biomass to various processes like resting, autoclaving and immobilization, finally resulting in metal entrapped in bead like structure. This technology is eco-friendly [63].

Alentulus fungi as biosorbent: The fungal biomass in the resting cell stage is mainly used in this procedure. Resting cells can be defined as the cells that can reproduce but have no metabolic activity [63]. The fungal strain was cultured in Erlenmeyer flasks, and after the exponential growth of the fungi, the biomass is harvested by centrifugation, and washed. Later, the resting biomass is subjected to immobilization by sodium alginate and calcium chloride, thereby producing calcium alginate beads entrapped with the fungal biomass.

Autoclaved biomass was prepared by autoclaving the pre grown resting biomass at $121^{\circ} \mathrm{C}$ and $15 \mathrm{lb}$ for 20 minutes. The autoclaved biomass can be used after filtration.

These resulting beads can be used for the removal of copper from the aqueous solutions.

Effect of temperature: Bioaccumulation of metals greatly depends on temperature and $\mathrm{pH}$ of solution since fungal growth gets adversely affected at extremes. Interestingly, A lentulus is known to perform consistently well over a broad $\mathrm{pH}$ and temperature range. With the increase of temperature from $20^{\circ} \mathrm{C}$ to $30^{\circ} \mathrm{C}$, there would be significant increase in biomass production and subsequently it would remain the same at $30-50^{\circ} \mathrm{C}$ [17]. Temperature below $24^{\circ} \mathrm{C}$ decreases fungal growth and enzyme activity.

Effect of pH: Biosorption of $\mathrm{Cu}^{2+}$ increases with decrease in $\mathrm{pH}$. Biosorption of $\mathrm{Cu}^{2+}$ ions by the resting, immobilized and autoclaved biomass decreases when $\mathrm{pH}$ of the solution increases [63]. The equilibrium time for resting, autoclave killed and immobilized biomass remains unaffected by the $\mathrm{pH}$. The decrease in adsorption with increase of $\mathrm{pH}$ may be due to the increase in electrostatic force of attraction between the sorbent ions and sorbent. At lower $\mathrm{pH}$ range due to high electrostatic force of attraction the copper removal is high and the surface of sorbent would be surrounded by hydronium ions which enhance copper ions interaction with the binding sites of biosorbent by greater attractive forces. At higher $\mathrm{pH}$ adsorption decreases may be due to the occupation of anionic species which retards the approach of such ions further towards sorbent surface.

\section{Biosorption of cadmium}

Many cases of itai-itai disease (osteomalacia with various grades of osteoporosis accompanied by severe renal tubular disease) and low molecular weight proteinuria have been reported among people living in contaminated areas in Japan and exposed to cadmium via food and drinking water. Cadmium accumulates mainly in kidneys and liver, but is also found in skeletal system, muscular system, and reproductive system and also in endocrine glands leading to renal dysfunction, hypertension, mutagenesis, and anaemia [64]. Application of fungal biomass to remove/recover heavy metals from industrial wastewater is economically valuable, technically sound, and socially acceptable and is attractive for industry.

Compared with the free biomass, immobilized microorganisms are considered more suitable for industrial application due to better mechanical strength, chemical stability, physical morphology, anti degradation ability and more importantly, repeated adsorptiondesorption characteristics [64]. Rhizomucor tauricus is chosen as biosorbent material because it is waste industrial fungus, relatively lack of information about the sorption ability.

Rhizomucor tauricus as biosorbent: The fungus Rhizomucor tauricus cultured using Potato dextrose broth is subjected to immobilization using the Sodium alginate gel and $\mathrm{CaCl}_{2}$ solution. The beads can be stored at $4^{\circ} \mathrm{C}$ and can be further used for equilibrium studies [64].

Effect of $\mathbf{p H}$ : The adsorption of metals decrease at low $\mathrm{pH}$ values because of competition for binding sites between cations and protons, while at $\mathrm{pH}$ higher than 7 , hydroxo species of the metals can be formed and do not bind to the adsorption sites on the surface of the adsorbent [64].

Effect of temperature: Temperature was found to favour biosorption. This may probably due to increase in activity of biomass as the temperature increases. The same trend was observed in case of dead fungal biomass [64].

\section{Biosorption of nickel}

Nickel ion is a common environmental pollutant which is considered as toxic (e.g. in concentrations of $15 \mathrm{mg} / \mathrm{L}$ ), especially to activated sludge bacteria, and its presence is detrimental to the operation of anaerobic digesters used in waste water treatment plants [65]. Waste streams from nickel electroplating industries and textile industries are the main sources of nickel environmental pollution [66]. Nickel plating industry has an important place among the industries releasing nickel ion to the aqueous medium. The nickel ion concentrations in different nickel plating industry wastewaters can vary $\left(10-1000 \mathrm{mg} \mathrm{Ni}^{2+} / \mathrm{L}\right)$ [65]. Traditional technologies for the removal of heavy metals, such as chemical reduction and precipitation, reverse osmosis, evaporative and ion exchange are often ineffective and/or very expensive when used for the removal of heavy metal ions to very low concentrations. New technologies are required that can reduce heavy metal concentrations to environmentally acceptable levels at affordable costs [65].

Biosorption has been studied in various types of biomass such as marine algae, bacteria, fungi, rice bran and agricultural wastes. Rice bran contains different vitamins, carbohydrates, potassium, nitrogen and phosphorus compounds, which induce to water to contact with it. These compounds not only have no pollution effects but they are nutritious to the plants. Therefore, the use of bran to eliminate pollution from water reveals the significance of the bran or natural products $[65,66]$.

Use of rice bran in biosorption: Both pure rice bran particles (not sieved) and rice bran particles with a size of $0.5-0.25 \mathrm{~mm}$ can be used for metal biosorption. Removal of Ni with rice bran particles (0.5-0.25 $\mathrm{mm}$ ) was optimum at a $\mathrm{pH}$ value of 7 but chemical precipitation occurs at $\mathrm{pH} 9$ and $\mathrm{pH} 11$. Therefore, studies were conducted at $\mathrm{pH} 9$ by Zafar et al. [66] on protonated rice bran and found that the optimum $\mathrm{pH}$ was 6.

To observe the effect of immobilization of fungus to the nickel uptake, R.arrhizus was immobilized onto pure rice bran and the treatment studies were conducted with this new biomass. At a $\mathrm{pH}$ of 3.0 the removal is greater than the value obtained in the study made only with pure rice bran. Also when the $\mathrm{pH}$ values 5.0 and 7.0 were 
assessed in point of removal efficiency, it was seen that better results were obtained compared with pure rice bran [65].

\section{Conclusion}

Microbial population is a highly diverse and a ubiquitous group among the living world. One of the novel features of the microbes relates to their versatility in utilizing a large numbers of natural and manmade compounds. This property proves highly valuable in bioremediation for the complete destruction and removal of pollutants. Microbial degradation is an environment friendly and cost-competitive alternative to chemical decomposition processes. Biosorption of heavy metals by microbial cells has been recognized as a potential alternative to existing technologies for recovery of heavy metals from industrial waste surroundings. Biosorption is more advantageous than conventional treatment methods in terms of cost, efficiency, regeneration of biosorbent and the extent of reduction of chemical or biochemical sludge.

\section{References}

1. Joe J, Kothari RK, Raval CM, Kothari CR, Akbari VG, et al. (2011) Decolorization of Textile Dye Remazol Black B by Pseudomonas aeruginosa CR- 25 Isolated from the Common Effluent Treatment Plant. J Bioremed Biodegrad 2: 118-124.

2. http://en.wikipedia.org/wiki/Pollution

3. Gursahani YH, Gupta SG (2011) Decolourization of textile effluent by a thermophilic bacteria Anoxybacillus rupiensis. J Pet Environ Biotechnol 2: 111115 .

4. Fayidh MA, Babuskin S, Sabina K, Sukumar M, Sivarajan M (2011) Integrated Approach to the Problems of Dye Wastewater by Sonolysis and Biological Treatment. J Microbial Biochem Technol 3: 60-66.

5. http://en.wikipedia.org/wiki/Pollution

6. Zamani S, Sendi JJ, Ghadamyari M (2011) Effect of Artemisia Annua L (Asterales: Asteraceae) Essential Oil on Mortality, Development, Reproduction and Energy Reserves of Plodia Interpunctella(Hübner). (Lepidoptera: Pyralidae). J Biofertil Biopestici 2: 105-111.

7. Shah D, Nandakumar S, Jaishankar GB, Chilakala S, Wang K, et al. (2011) PreTerm Exposure Patterns in Neonatal Intensive Care Unit Alters Immunological Outcome in Neonates. J Aller Ther 2: 106-113.

8. Mirdamadian SH, Emtiazi G, Golabi MH, Ghanavati H (2010) Biodegradation of Petroleum and Aromatic Hydrocarbons by Bacteria Isolated from PetroleumContaminated Soil. J Pet Environ Biotechnol 1: 102-107.

9. Amin GA (2010) A Potent Biosurfactant Producing Bacterial Strain for Application in Enhanced Oil Recovery Applications. J Pet Environ Biotechnol 1: 104-109

10. Ali Elredaisy SM (2010) Ecological Benefi ts of Bioremediation of Oil Contaminated Water in Rich Savannah of Palogue, Upper Nile Area-Southern Sudan. J Bioremed Biodegrad 1: 103-110.

11. Sethy NK, Jha VN, Shukla AK, Sahoo SK, Tripathi RM, et al. (2011) Natural Radionuclide ( $U$ and226Ra) in Water, Sediment, Fish and Plant Species in the Aquatic Environment around Uranium Mining and Ore processing Site at Jaduguda, India. J Ecosys Ecograph 1: 103-109.

12. Sethy NK, Jha VN, Sahoo SK, Shukla AK, Tripathi RM, et al. (2011) Ground Water Ingestion Dose Due to Intake of Radionuclide (Natural U and 226Ra) to Population Around Uranium Mining Complex at Jaduguda. J Ecosys Ecograph 1: 104-109.

13. Kumar NK, Reddy DSR, Venkateswarlu P (2010) Application of Response Surface Methodology for Optimization of Chromium Biosorption from an Aqueous Solution onto Syzigium cumini (java) Seed Powder. J Microbial Biochem Technol 2: 20-27.

14. Mathiyazhagan N, Natarajan D (2011) Bioremediation on effluents from Magnesite and Bauxite mines using Thiobacillus Spp and Pseudomonas Spp. J Bioremed Biodegrad 2: 115-121.
15. Wasi S, Tabrez S, Ahmad M (2010) Isolation and Characterization of a Pseudomonas fluorescens Strain Tolerant to Major Indian Water Pollutants. J Bioremed Biodegrad 1: 101-106.

16. Mathiyazhagan N, Natarajan D (2011) Bioremediation on effluents from Magnesite and Bauxite mines using Thiobacillus Spp and Pseudomonas Spp. J Bioremed Biodegrad 2: 115-121.

17. http://en.wikipedia.org/wiki/Heavy_metal_\%28chemistry\%29

18. Matthew MM, Henke KR, Atwood DA (2002) Effectiveness of Commercia Heavy Metal Chelators with New Insights for the Future in Chelate Design. J Hazard Mater 92: 129-142.

19. Ahalya N, Ramachandra TV, Kanamadi RD (2003) Biosorption of heavy metals Res J Chem Environ 7: 71-79.

20. Aghamiri SF, Kabiri K, Emtiazi G (2011) A Novel Approach for Optimization of Crude Oil Bioremediation in Soil by the Taguchi Method. J Pet Environ Biotechnol 2: 108-114.

21. Gnanamani A, Kavitha V, Radhakrishnan N, Mandal AB (2010) Bioremediation of Crude Oil Contamination Using Microbial Surface-Active Agents: Isolation, Production and Characterization. J Bioremed Biodegrad 1: 107-115.

22. Komal S Gomare and G Gyananath (2011) Potential of Bacillus sp. Isolated from the paper industry effluent for the waste water Treatment. J Bioremed Biodegrad World congress on Biotechnology.

23. Surani JJ, Akbari VG, Purohit MK, Singh SP (2011) Pahbase, a Freely Available Functional Database of Polycyclic Aromatic Hydrocarbons (Pahs) Degrading Bacteria. J Bioremed Biodegrad 2: 116-118.

24. Ramya M, Iyappan S,ManjuA, Jiffe JS (2010) Biodegradation and Decolorization of Acid Red by Acinetobacter radioresistens. J Bioremed Biodegrad 1: 105111.

25. Djefal-Kerrar A, Ouallouche-Abdoun K, Chouikrat R, El-Kahina YG, NacerKhodja A, et al. (2011) Study of Bacterium Fixation Stability on Gamma Radiation Synthesized Carriers to Improve Degradation. J Bioremed Biodegrad 2: 117-124.

26. Gayathri KV, Vasudevan N (2010) Enrichment of Phenol Degrading Moderately Halophilic Bacterial Consortium from Saline Environment. J Bioremed Biodegrad 1: 104-110.

27. Jame SA, Rashidul Alam AKM, Fakhruddin ANM, Alam MK (2010) Degradation of Phenol by Mixed Culture of Locally Isolated Pseudomonas Species. J Bioremed Biodegrad 1: 102-106.

28. Chin SP, Ismail NS, Al-Ashraf Abdullah A, Yahya ARM (2010) Aerobic Degradation of Volatile Fatty Acids by Bacterial Strain Isolated from Rivers and Cow Farm in Malaysia. J Bioremed Biodegrad 1:111 doi:10.4172/21556199.1000111.

29. Narasimhulu K, Rao PS, Vinod AV (2010) Isolation and Identification of Bacterial Strains and Study of their Resistance to Heavy Metals and Antibiotics. J Microbial Biochem Technol 2: 74-76.

30. Sonoki T, Kajita S, Uesugi M, Katayama Y, limura Y (2011) Effective Removal of Bisphenol a from Contaminated Areas by Recombinant Plant Producing Lignin Peroxidase. J Pet Environ Biotechnol 2: 105-108.

31. Ghoodjani E, Bolouri SH (2011) Experimental Study of $\mathrm{CO}_{2}-E O R$ and N2-EOR with Focus on Relative Permeability Effect. J Pet Environ Biotechnol 2: 106111.

32. Arora PK, Srivastava A, Singh VP (2010) Application of Monooxygenases in Dehalogenation, Desulphurization, Denitrification and Hydroxylation of Aromatic Compounds. J Bioremed Biodegrad 1: 110-118

33. Zhang B, Shahbazi A (2011) Recent Developments in Pretreatment Technologies for Production of Lignocellulosic Biofuels. J Pet Environ Biotechnol 2: 108-116.

34. Padilla-Gasca E, López AL (2010) Kinetics of Organic Matter Degradation in an Upflow Anaerobic Filter Using Slaughterhouse Wastewater. J Bioremed Biodegrad 1: 106-112.

35. Padilla-Gasca E, López-López A, Gallardo-Valdez J (2011) Evaluation of Stability Factors in the Anaerobic Treatment of Slaughterhouse Wastewater. $J$ Bioremed Biodegrad 2: 114-119. 
Citation: Sameera V, Naga Deepthi CH, Srinu Babu G, Ravi Teja Y (2011) Role of Biosorption in Environmental Cleanup. J Microbial Biochem Technol R1:001. doi:10.4172/1948-5948.R1-001

Page 8 of 8

36. Santhoskumar AU, Palanivelu K, Sharma SK, Nayak SK (2010) A New Synthesis of Nickel 12-Hydroxy Oleate Formulation to Improve Polyolefi n's Degradation. J Bioremed Biodegrad 1: 108-117.

37. Santhoskumar AU, Palanivelu K, Sharma SK, Nayak SK (2010) Comparison of Biological Activity Transistion Metal 12 Hydroxy oleate on Photodegradation of Plastics. J Bioremed Biodegrad 1: 109-117.

38. Elbanna K, Hassan G, Khider M, Mandour R (2010) Safe Biodegradation of Textile Azo Dyes by Newly Isolated Lactic Acid Bacteria and Detection of Plasmids Associated With Degradation. J Bioremed Biodegrad 1: 110-116.

39. Olusola SA, Anslem EE (2010) Bioremediation of a Crude Oil Polluted Soil with Pleurotus Pulmonarius and Glomus Mosseae Using Amaranthus Hybridus as a Test Plant. J Bioremed Biodegrad 1: 113-119.

40. Bordenave S, Goni-Urriza M, Caumette P, Duran R (2009) Differential Display Analysis of cDNA Involved in Microbial Mats Response after Heavy Fuel Oil Contamination. J Microbial Biochem Technol 1: 1-4.

41. Kurnaz SU, Buyukgungor H (2009) Assessment of Various Biomasses in the Removal of Phenol from Aqueous Solutions. J Microbial Biochem Technol 1: 47-50.

42. Joe J, Kothari RK, Raval CM, Kothari CR, Akbari VG, et al. (2011) Decolorization of Textile Dye Remazol Black B by Pseudomonas aeruginosa CR- 25 Isolated from the Common Effluent Treatment Plant. J Bioremed Biodegrad 2: 118-124.

43. Shrivastava R, Purohit H, Phale PS (2011) Metabolism and Preferentia Utilization of Phenylacetic acid and 4-Hydroxyphenylacetic Acid in Pseudomonas putida CSV86. J Bioremed Biodegrad 2: 120.

44. Begum N, Sharma B, Pandey RS (2010) Evaluation of Insecticidal Efficacy of Calotropis Proceraand Annona Squamosa Ethanol Extracts Against Musca Domestica. J Biofertil Biopestici 1: 101-107.

45. http://en.wikipedia.org/wiki/Biosorption

46. Chang NB (2011) Making a Progress to Speed up the Nitrification and Denitrification Processes in Novel Biosorption Activated Media: Can Archaea be in Concert with Anammox? J Bioprocess Biotechniq 1: 103-108.

47. Tarangini, K (2009) Biosorption of Heavy Metals using Individual and Mixed Cultures of Pseudomonas Aeruginosa and Bacillus. Thesis submitted in partial fulfilment for the award of the degree, National Institute of Technology, Rourkela

48. Engade KB, Gupta SG (2010) Decolorization of Textile Effluent by Immobilized Aspergillus terreus. J Pet Environ Biotechnol 1: 101-103.

49. Mihova St, Godjevargova T (2000) Biosorption of Heavy metals from aqueous solutions. Journal of International Research Publication.

50. Hussein H, Ibrahim SF, Kamal K, Hassan M (2004) Biosorption of Heavy metals from waste water using Pseudomonas sp. Electron J Biotechnol 7.

51. Niazi A, Mahmoudzadeh S, Najafi V (2011) Biosorption of Fe from Aqueous Solutions by Syringa Vulgaris Tree Leaves International. Journal of Chemical and Environmental Engineering 2: 33-38.

52. Poornima K, Karthik L, Swadhini SP, Mythili S, Sathiavelu A (2010) Degradation of Chromium by Using a Novel Strains of Pseudomonas Species. J Microbial Biochem Technol 2: 95-99.

53. Sebastián B, Luis S, Juan G, Silvia G, María F (2010) Thermodynamic and Dynamic of Chromium Biosorption by Pectic and Lignocellulocic Biowastes. J Water Resource and Protection 2: 888-897.

54. Srividya K, Kaustubha M (2011) Influence of Temperature on Equilibrium, Kinetic and Thermodynamic Parameters of Biosorption of $\mathrm{Cr}(\mathrm{VI})$ onto Fish Scales as Suitable Biosorbent. Journal of Water Resource and Protection 3: 429-439.

55. Murugesan AG , S Maheswari (2007) Uptake of hexavalent chromium from aqueous solution employing live, dead and immobilized bacterial biomass. $J$ Appl Sci Environ Manage 11: 71-75

56. Murugesan AG, John Ruby (2005) Biotechnological application for an effective management of liquid and solid wastes. Biotechnology in Environmental
Management. A.P.H.Publishing Corporation. New Delhi. 653-676.

57. Rajesh D, Anju H, Radha S, Poonam AS (2011) Saccharomyces cerevisiae: a potential biosorbent for biosorption of uranium. International Journal of Engineering Science and Technology 3: 5397-5407.

58. Mohammad HK, Ali RK, Behrouz M, Mohammad FZ, Eza J (2006) Biosorption of uranium from aqueous solutions by nonliving biomass of marine algae Cystoseira indica. Electron J Biotechnol 9: 100-106.

59. Amuda OS, Giwa AA, Bello IA (2007) Removal of heavy metal from industria waste water using modified activated coconut shell carbon. Biochem Eng J 36 174-181.

60. El-Said AG (2010) Biosorption of $\mathrm{Pb}$ (II) Ions from Aqueous Solutions Onto Rice Husk and its Ash. Journal of American Science 6: 143-150.

61. Yang L, Brigitte $\mathrm{H}$, Harald $\mathrm{H}$ (2011) Biosorption of $\mathrm{Cu}(\mathrm{II})$ lons from Aqueous Solution by Red Alga (Palmaria Palmata) and Beer Draff. J Materials Sciences and Applications 2: 70-80.

62. Perdikaki K, Mason CF (1998) Impact of Road Run-off on Receiving Streams in Eastern England. Water Res 33: 1627-1633.

63. Shipra J, Dikshit SN, Pandey G (2011) Biosorption :An eco- friendly alternative for $\mathrm{Cu} 2+$ removal by using A lentulus fungal strain. International Journal of Engineering Science and Technology 3: 4518-4522.

64. Kumar KK, Prasad MK, Sarma GVS, Murthy CVR (2009) Removal of Cd (II) from Aqueous Solution Using Immobilized Rhizomucor Tauricus. J Microbial Biochem Technol 1: 15-21.

65. Gurel L, senturk I, Bahadir T, Buyukgungor H (2010) Treatment of Nicke Plating Industrial Wastewater by Fungus Immobilized onto Rice Bran. J Microbial Biochem Technol 2: 34-37

66. Zafar MN, Nadeem R, Hanif MA (2007) Biosorption of nickel from protonated rice bran. J Hazard Mater 143: 478-485. 